\title{
GICS for grinding process optimization
}

Holesovsky Frantisek, Naprstkova Natasa, Novak Martin.

J. E. Purkyně University in Ústí nad Labem, Faculty of Production Technology and Management, Na Okraji 1001, 400 96 Ústí nad Labem, Czech Republic, holesovsky@fvtm.ujep.cz

The article deals with the automation of the grinding machine duty cycle. There are both described, the problems of the automation of the duty cycle and the present state summarised in this paper. The control systems of grinding cycle run from the experiences and process knowledge. Real GICS (Grinding Intelligent Control System) must be founded on the process monitoring and to create own control system with principal parameters of grinding. Cutting speed, workpiece motion speed, depth of cut, volume of coolant, course of cutting forces and other process parameters can form single control components at the adequate process knowledge. At some control systems description the authors assume the future possible direction of development, considering possibilities in the use of the expert and intelligent systems.

Keywords: grinding, grinding wheel, adaptive system, expert system, intelligent system

\section{Acknowledgement}

Above mentioned results were created by means of national project GA CR No.101/09/0504.

\section{References}

[1] ALlanSON, D.R., KELly,S., TERRY, S., MORUZZI, J.L., ROWE, W.B. Coping with Compliance in the Control of Grinding Processes. CIRP, 38/1/1989, p. 311-314

[2] BRINKSMEIER,E.,WERNER,F. Monitoring of Grinding Wheel Wear, Annals of the CIRP, vol.41/1/1992, p.373-376

[3] GUI J. LIU, YA D. GONG, WAN S. WANG Intelligent Monitor and Control System for Grinding Process. Key Engineering Materials, vol.304-305, 2006, pp.535-539

[4] HOLEŠOVSKÝ F. Meaning of Time Course of Cutting Force at Cylindrical Grinding, TU Liberec, 1997, Thesis, pp.15-16, 55-57, 114-118

[5] HOLEŠOVSKÝ F. The Quality Control of the Surface at the Cylindrical Surface Grinding, Proceedings The $14^{\text {th }}$ International Conference ICPR, Osaka 1997, Japan, pp.690-693

[6] HUANG, X., GAO, Y. A discrete system model for form error control in surface grinding. International Journal of Machine Tools and Manufacture, vol.50 (3), 2011, pp. 219-230

[7] KOCMAN, K. Application of magnetic correlation analysis on the choice and correction of cutting parameters for automated manufacturing systems. Manufacturing Technology, vol.XI, 2011, pp. 28-32

[8] LI, P., WANG, J. Automatic control system of grinding process. Proceedings of the 6th International Forum on Strategic Technology, IFOST 2011, art. no. 6021045, pp. 382-385

[9] LIU, G.J., GONG, Y.D., WANG, W.S. Intelligent monitor and control system for grinding process. Key Engineering Materials, vol. 304-305, 2006 , pp. 535-539

[10] LUKOVICS I., SÝKOROVÁ L. Determination of Cutting Property of Grinding Wheels forHigh Power Grinding, Tools 99, Zlín, 1999, p. 96-102

[11] MÁDL J., ČERMÁK J., VRABEC M. Computational techniques in Manufacturing Technology, Acta Polytechnica, ČVUT, 2000, vol.40, No.4, pp.94-100

[12] MARINESCU, D.I., HITCHINER, M. et al. Handbook of Machining with Grinding Wheels. CRC Press, 2007

[13] NOBORU U, OBUCHI Y., MATSUO T., NOMURA H. Expert System for Grinding. Proceeding, Third International Grinding Conference, Fontana 1988, p. 622/1-11

[14] NOVAK, M. Surface quality of hardened steels after grinding. Manufacturing Technology, vol. 11, 2011, pp.55-59

[15] NOVAK-MARCINČIN, J., KURIC, I., LEGUTKO, S., NOVÁKOVÁ, L. Computer Aided Technical Preparation of Production. University of Žilina, 2011 
[16] ROWE W.B., CHEN X., MILLS B. Towards an Adaptive Strategy for Dressing in Grinding Operations, Proceedings of the 31 st International Matador Conference

[17] TÖNSHOFF H.K., PETERS J., INASAKI I., PAUL T. Modelling and Simulation of Grinding Processes, Annals of the CIRP, vol.41/2/1992, p.677-688

Paper number: M201205

Manuscript of the paper recieved in 2011-11-21. The reviewers of this paper: Prof. Imrich Lukovics, MSc., Ph.D. and Prof. Dr. h. c. Karol Vasilko, $M S c ., S c . D$. 